\title{
TUMPANG TINDIH REGULASI DALAM PENYUSUNAN RENCANA KERJA PEMERINTAH NAGARI (RKP NAGARI)
}

\author{
SURYANINGSIH, SILSILA ASRI
}

Sekolah Tinggi Ilmu Sosial dan Ilmu Politik Imam Bonjol, aseh2309@gmail.com, latansa2003@yahoo.com

\begin{abstract}
Every year the nagari government prepares a work plan before the determination of the APBNagari. The process of preparing this planning document is usually based on the Minister of Home Affairs Regulation No. 114/2014, but in 2020 the Minister of Village Regulation No. 21/2020 regulates the same. There are differences in the process of preparing the RKP Desa regulated by the two regulations. The purpose of this paper is to see the impact of overlapping regulations in the preparation of the RKP Nagari in Lima Puluh Kota Regency. The method used in this research is descriptive qualitative. The results of the study indicate that there are 2 impacts of the overlapping regulations, First, the District Government of Lima Puluh Kota is slow in responding to the latest regulations so that the regent's regulations governing the Technical Guidelines for the Preparation of RPJM, RKP, and Implementation of Nagari Development Activities have not been revised so that the process the preparation of the RKP applied by the nagari varies, some are implemented according to the regent's regulations and some are in accordance with the village minister's regulations. Second, the emergence of internal disputes within the Nagari government because they are confused about implementing the process of preparing the Nagari RKP in accordance with the regulation of Permendagri No. 114/2014 or Village Minister Regulation No. 21/2020.
\end{abstract}

Keywords: Village, Regulation, Development Planning

Abstrak: Setiap tahunnya pemerintah nagari menyusun rencana kerja sebelum ditetapkannya $A P B$ Nagari. Proses penyusunan dokumen perencanaan ini biasanya didasarkan pada Peraturan Menteri Dalam Negeri No. 114/2014, akan tetapi pada tahun 2020 lahirlah Peraturan Menteri Desa No. 21/2020 mengatur hal yang sama. Ada perbedaan proses penyusunan RKP Desa yang diatur oleh kedua regulasi tersebut. Tujuan dari tulisan ini adalah untuk melihat dampak dari tumpang tindih regulasi dalam penyusunan RKP Nagari tahun 2022 di Kabupaten Lima Puluh Kota. Metode yang digunakan dalam penelitian ini adalah kualitatif deskriptif. Hasil penelitian menunjukkan bahwa ada 2 dampak dari tumpang tindih regulasi tersebut, yakni: Pertama, Pemerintah Kabupaten Lima Puluh Kota lambat dalam merespon regulasi terbaru tersebut sehingga peraturan bupati yang mengatur tentang Petunjuk Teknis Penyusunan RPJM, RKP, dan Pelaksanaan Kegiatan Pembangunan Nagari belum direvisi sehingga proses penyusunan RKP yang diterapkan oleh nagari berbeda-beda, ada yang menerapkan sesuai dengan peraturan bupati dan ada yang sesuai dengan peraturan menteri desa. Kedua, timbulnya perselisihan di internal pemerintahan nagari karena bingung ingin menerapkan proses penyusunan RKP Nagari sesuai dengan regulasi Permendagri No. 114/2014 atau Peraturan Menteri Desa No. 21/2020.

Kata Kunci: Nagari, RKP Nagari, Tumpang Tindih Regulasi.

\section{A. Pendahuluan}

Undang-undang No. 6 tahun 2014 menempatkan desa sebagai subjek (aktor) dalam pembangunan. Ketika desa ditetapkan sebagai aktor utama maka segala perencanaan, pembiayaan, dan pelaksanaan pembangunan dilakukan oleh desa. Dalam pasal 79 undangundang desa tersebut mensyaratkan pemerintah desa untuk menyusun perencanaan pembangunan desa yang meliputi pertama, Rencana Pembangunan Jangka Menengah desa (RPJMDesa) untuk jangka waktu 6 tahun; dan kedua, Rencana Kerja Pemerintah desa (RKPDesa) untuk jangka waktu 1 tahun. Kedua dokumen tersebut nantinya ditetapkan dalam Peraturan Desa. 
Regulasi yang kemudian menjadi petunjuk teknis oleh desa dalam menyusun kedua dokumen perencanaan tersebut adalah Peraturan Menteri Dalam Negeri (Permendagri) No. 114 tahun 2014 Tentang Pedoman Pembangunan Desa. Regulasi ini lahir pada tanggal 31 Desember 2014 selang beberapa bulan setelah undang-undang desa disahkan pada tanggal 15 Januari 2014. RKP Desa merupakan penjabaran dari RPJM Desa yang disusun sesuai dengan informasi dari pemerintah kabupaten/kota terkait dengan pagu indikatif desa dan rencana kegiatan pemerintah, pemerintah daerah provinsi, dan pemerintah daerah kabupaten/kota. RKP Desa menjadi dasar dalam penetapan APBDesa.

Pada tanggal 22 Oktober 2019 keluarlah Peraturan Menteri Desa, Pembangunan Daerah Tertinggal, dan Transmigrasi No. 17 tahun 2019 tentang Pedoman Umum Pembangunan dan Pemberdayaan Masyarakat Desa. Regulasi ini juga mengatur tentang tahapan dalam penyusunan RKP Desa. Dalam hal ini terlihat adanya 2 (dua) regulasi yang mengatur penyusunan RKP Desa dan kedua regulasi ini memiliki pengaturan tahapan yang berbeda dalam penyusunan RKP Desa. Peraturan menteri yang tumpang tindih dalam hal jenis, hirarki, dan materi muatan disebabkan oleh kurangnya pemahaman terkait peraturan kebijakan hingga ego sektoral setiap kementrian (Chandra, 2019). Hal ini tentu saja menyulitkan pemerintah desa sebagai pelaksana teknis dari kebijakan yang dikeluarkan oleh beberapa kementrian, yakni Kementrian Dalam Negeri, Kementrian Desa, Pembangunan Daerah Tertinggal, dan Transmigrasi, dan Kementrian Keuangan.

Di Kabupaten Lima Puluh Kota Provinsi Sumatera Barat petunjuk teknis penyusunan RKP Nagari diatur dalam Peraturan Bupati No. 28 Tahun 2019 tentang Petunjuk Teknis Penyusunan Rencana Pembangunan Jangka Menengah Nagari, Rencana Kerja Pemerintah Nagari, dan Pelaksanaan Kegiatan Pembangunan Nagari. Peraturan Bupati ini tergolong yang paling lambat dikeluarkan karena lahir setelah 5 (lima) tahun sejak diundangkannya Permendagri No. 114/2014. Peraturan bupati ini merupakan permintaan dari pasal 89 Permendagri No. 114/2014 yang menyebutkan bahwa petunjuk teknis penyusunan RPJM Desa dan RKP Desa serta petunjuk teknis pelaksanaan kegiatan pembangunan Desa diatur lebih lanjut dengan peraturan bupati/walikota.

Berbagai penelitian terkait dengan penyusunan RKP Desa ini telah banyak dilakukan oleh peneliti sosial. Hasil kajian Suprastiyo dan Musta'ana (2018) menunjukkan bahwa Implementasi Penyusunan RKP Desa Trucuk belum sesuai dengan Peraturan Menteri Dalam Negeri Republik Indonesia Nomor 114 Tahun 2014 Tentang Pedoman Pembangunan Desa, hal ini terjadi karena penyusunan RKP Desa Trucuk masih mengacu pada Panduan Teknis Musyawarah Perencanaan Pembangunan Kabupaten Bojonegoro tahun 2017 yang belum diselasarkan dengan Peraturan Menteri Dalam Negeri Republik Indonesia Nomor 114 Tahun 2014 Tentang Pedoman Pembangunan Desa (Suprastiyo \& Musta'ana, 2019). Selain itu, penelitian yang dilakukan oleh Mali dkk tentang koordinasi pemerintah desa dalam penyusunan RKP Desa menunjukkan bahwa adanya koordinasi horizontal antara pemerintah desa dengan Badan Permusyawaratan Desa (BPD) dalam penyusunan RKP Desa di Desa Manumutin Silole Kecamatan Sasitamean Kabupaten Malaka (Mali et al., 2019). Penelitian tentang RKP Desa juga dilakukan oleh Rudiadi dkk yang berfokus pada kinerja pemerintahan desa dalam membahas dan menyusun RKP Desa. Hasil penelitiannya menunjukkan bahwa kinerja pemerintahan desa belum terlaksana dengan baik yang disebabkan oleh beberapa faktor, yakni kurangnya kerjasama antar lembaga pemerintahan desa, masih adanya program kerja yang tidak tepat sasaran, dan kurang tanggapnya pemerintahan desa dalam menyerap aspirasi dan keinginan masyarakat desa (Rudiadi et al., 2021).

Dari beberapa penelitian yang telah dilakukan diatas, belum ada yang melakukan penelitian terkait dengan dampak tumpang tindih regulasi dalam penyusunan RKP Desa. Berdasarkan hal terebut maka perlu dilakukan penelitian untuk melihat bagaimana respon pemerintah Kabupaten Lima Puluh Kota dengan keluarnya Permendesa No. 17/2019 yang direvisi menjadi Permendesa No. 21/2020 Tentang Pedoman Umum Pembangunan dan Pemberdayaan Masyarakat Desa yang juga mengatur tahapan dalam penyusunan RKP serta 
bagaimana dampak tumpang tindih regulasi tersebut dalam penyusunan RKP Nagari di Kabupaten Lima Puluh Kota.

\section{B. Metodologi Penelitian}

Metode yang digunakan dalam penelitian ini adalah kualitatif deskriptif. Penelitian deskriptif digunakan jika ada pengetahuan atau informasi tentang gejala sosial yang akan diselidiki atau dipermasalahkan (Silalahi, 2010). Dengan metode ini nantinya dapat mengungkapkan dampak dari tumpang tindih regulasi dalam penyusunan RKP Nagari di Kabupaten Lima Puluh Kota. Dalam pengumpulan data primer dan sekunder digunakan teknik wawancara dan dokumentasi.

\section{Hasil dan Pembahasan}

\section{Perencanaan Pembangunan Desa}

Jika kita berbicara tentang desa, maka akan menimbulkan 3 penafsiran atau pengertian, yakni pengertian secara sosiologi, pengertian secara ekonomi, dan pengertian secara politik (Maschab, 2013). Desa secara Sosiologi diartikan sebagai suatu bentuk kesatuan masyarakat atau komunitas penduduk yang tinggal dan menetap dalam suatu lingkungan, diantara mereka saling mengenal dengan baik dan corak kehidupan mereka relatif homogen, dan bergantung dengan alam. Kemudian, desa secara ekonomi diartikan sebagai suatu lingkungan masyarakat yang berusaha memenuhi kebutuhan hidupnya sehari-hari dari apa yang disediakan alam di sekitarnya. Dan terakhir, pengertian desa secara politik diartikan sebagai suatu organisasi pemerintahan atau organisasi kekuasaan yang secara politik mempunyai wewenang tertentu karena merupakan bagian dari pemerintahan negara.

Pengertian desa secara politik ini dapat dilihat dari regulasi yang digunakan dalam pengaturan desa. Desa atau yang disebut dengan nama lain didefinisikan sebagai sebagai kesatuan masyarakat hukum yang memiliki batas wilayah yang berwenang untuk mengatur dan mengurus urusan pemerintahan, kepentingan masyarakat setempat berdasarkan prakarsa masyarakat, hak asal usul, dan/atau hak tradisional yang diakui dan dihormati dalam sistem pemerintahan NKRI (Pasal 1 ayat (1) UU No. 6/2014 tentang Desa). Dari definisi diatas terlihat bahwa desa memiliki kewenangan untuk mengatur dan mengurus urusan pemerintahan dan kepentingan masyarakat berdasarkan hak asal usul/hak tradisional yang diakui. Kewenangan desa tersebut meliputi kewenangan di bidang penyelenggaraan pemerintahan desa, pelaksanaan pembangunan desa, pembinaan kemasyarakatan desa, dan pemberdayaan masyarakat desa (Pasal 18 UU No. 6/2014 tentang Desa). Ada beberapa bentuk dari kewenangan yang dimiliki desa tersebut, yakni a) kewenangan berdasarkan hak asal usul; b) kewenangan lokal berskala desa; c) kewenangan yang ditugaskan oleh Pemerintah, Pemerintah Daerah Provinsi, Pemerintah Daerah Kabupaten/Kota; d) kewenangan lain yang ditugaskan oleh Pemerintah, Pemerintah Daerah Provinsi, Pemerintah Daerah Kabupaten/Kota (Pasal 19 UU No. 6/2014 tentang Desa). Terjadi ambivalensi terkait dengan kewenangan desa jika dilihat dari pasal tersebut, dimana kewenangan desa merupakan limpahan dari kewenangan pemerintah pusat dan daerah meskipun desa juga diberikan kewenangan hak asal usul dan lokal berskala desa (Abikusna, 2020).

Penjelasan lebih lanjut mengenai kewenangan desa ini diatur dalam Peraturan Menteri Desa, Pembangunan Daerah Tertinggal dan Transmigrasi No. 1 tahun 2015 tentang Pedoman Kewenangan Berdasarkan Hak Asal Usul dan Kewenangan Lokal Berskala Desa. Di dalam pasal 7 peraturan ini menjelaskan bahwa kewenangan lokal berskala desa meliputi bidang pemerintahan desa, bidang pembangunan desa, kemasyarakatan desa, dan pemberdayaan masyarakat desa. Untuk kewenangan lokal berskala desa bidang pembangunan desa ini meliputi; pelayanan dasar desa, sarana dan prasarana desa, pengembangan ekonomi lokal desa, dan pemanfaatan sumberdaya alam dan lingkungan desa. Pelaksanaan kewenangan berdasarkan hak asal usul dan kewenangan lokal berskala desa menurut pasal 20 UU No. 6 tahun 2014 diatur dan diurus oleh desa. Dalam melaksanakan pembangunan yang menjadi kewenangan lokal berskala desa, pemerintah desa perlu menyusun perencanaan desa, 
penganggaran, pelaksanaan pembangunan, pelaporan serta monitoring dan evaluasi yang melibatkan seluruh komponen masyarakat desa (Buku Bantu Pengelolaan Pembangunan Desa, 2016).

Peraturan Menteri Dalam Negeri No. 114 tahun 2014 dijelaskan bahwa perencanaan pembangunan desa adalah proses tahapan kegiatan yang diselenggarakan oleh pemerintah desa dengan melibatkan Badan Permusyawaratan Desa dan unsur masyarakat secara partisipatif guna pemanfaatan dan pengalokasian sumber daya desa dalam rangka mencapai tujuan pembangunan desa. Dari pengertian diatas dapat ditarik kesimpulan bahwasannya perencanaan pembangunan desa merupakan; 1) proses tahapan kegiatan; 2) diselenggarakan antara pemerintah desa dengan melibatkan Badan Permusyawaratan Desa (BPD) dan unsur masyarakat desa; 3) untuk pemanfaatan dan pengalokasian sumber daya desa. Perencanaan pembangunan desa ini memberikan arah bagi kepala desa dan pemangku kepentingan lainnya untuk mencapai visi dan misi desa, menyelaraskan pelaksanaan kebijakan pembangunan baik di tingkat pusat, provinsi dan daerah kabupaten/kota serta pengelolaan sumber daya yang dimilikinya (Buku Bantu Pengelolaan Pembangunan Desa, 2016).

Perencanaan pembangunan desa ini dilakukan secara berjangka yang meliputi, Rencana Pembangunan Jangka Menengah Desa (RPJMDes) yang disusun untuk jangka waktu 6 tahun dan Rencana Kerja Pemerintah Desa (RKPDes) yang merupakan rencana pembangunan tahunan desa dan disusun berdasarkan RPJMDesa. Menurut (Bachrein, 2010) dalam penyusunan perencanaan tersebut harus memperhatikan: a) Pembangunan perdesaaan disesuaikan dengan strategi pembangunan nasional dan daerah; b) Pemanfaatan potensi desa secara rasional dan optimal tanpa mengganggu kesimbangan dan kelestarian alam; c) Pengembangan landasan yang kuat bagi masyarakat desa untuk tumbuh dan berkembang atas kemampuan sendiri; d) Pemanfaatan ilmu pengetahuan dan teknologi; dan e) Mendorong masyarakat desa agar memegang peranan aktif dalam kegiatan pembangunan.

\section{Proses Penyusunan Rencana Kerja Pemerintah Desa (RKP Desa)}

Rencana Kerja Pemerintah Desa atau biasa disingkat dengan RKP Desa merupakan rencana pembangunan desa yang merupakan penjabaran dari RPJM Desa yang disusun setiap tahunnya. Penyusunan terkait dengan RKP ini diatur dalam pasal 79 ayat (2b) UU No. 6 tahun 2014, Pasal 118 Peraturan Pemerintah (PP) No. 43 tahun 2014 yang telah direvisi menjadi PP No. 47 tahun 2015 tentang Peraturan Pelaksana UU No. 6 Tahun 2014 Tentang Desa dan Peraturan Menteri Dalam Negeri (Permendagri) No. 114 Tahun 2014 tentang Pedoman Pembangunan Desa. Dalam Permendagri tersebut ditegaskan bahwa dalam penyusunan RKP Desa harus melibatkan masyarakat desa.

Permendagri No. 114/2014 pasal 30 secara lebih rinci mengatur bagaimana tahapan dalam penyusunan RKP Desa, yakni; 1) Musyawarah Desa dalam rangka penyusunan rencana pembangunan desa; 2) Pembentukan tim RKP Desa; 3) Pencermatan pagu indikatif desa dan penyelarasan program/kegiatan yang masuk ke desa; 4) Pencermatan ulang dokumen RPJM Desa; 5) Penyusunan rancangan RKP Desa; 6) Musyawarah Perencanaan Pembangunan Desa untuk penyusunan RKP Desa; 7) Penetapan RKP Desa; 8) Perubahan RKP Desa; dan 9) Pengajuan daftar usulan RKP Desa.

Dari tahapan tersebut terlihat bahwasannya sebelum dilakukan penyusunan rancangan RKP Desa perlu dilaksanakannya musyawarah Desa. Salah satu hasil dari pelaksanaan musyawarah desa ini adalah terbentuknya tim RKP Desa yang kemudian tim ini akan bekerja untuk melakukan pencermatan terhadap pagu indikatif desa dan penyelarasan program/kegiatan yang masuk ke desa, pencermatan ulang dokumen RPJM Desa, dan kemudian hal tersebut disusun menjadi Rancangan RKP Desa. Setelah Rancangan RKP Desa selesai disusun oleh TIM RKP Desa, maka tim menyerahkan hasil kerjanya kepada pemerintah desa. Dan kemudian pemerintah desa melakukan Musyawarah perencanaan Pembangunan Desa (Musrenbangdes) guna menentukan prioritas kegiatan yang telah disusun oleh tim RKP Desa. Jika setelah dibawa ke Musrenbang RKP ada perubahan, maka tim RKP Desa 
memperbaiki kembali rancangan RKP Desa tersebut. Setelah rancangan RKP Desa telah diperbaiki maka Kepala Desa bersama dengan Badan Permusyawaratan Desa (BPD) melakukan penetapan Rancangan RKP Desa. RKP Desa ini ditetapkan melalui Peraturan Desa.

RKP Desa dapat dilakukan perubahan apabila terjadi peristiwa khusus (bencana alam, krisis politik, krisis ekonomi dan/atau kerusuhan sosial yang berkepanjangan) dan terdapat perubahan mendasar atas kebijakan pemerintah, pemerintah daerah provinsi dan pemerintah daerah kabupaten/kota. Tahapan yang terakhir adalah pengajuan Daftar Usulan RKP Desa (DU RKP) kepada bupati/walikota melalui camat. Penyampaian DU RKP ini paling lambat tanggal 31 Desember tahun berjalan untuk menjadi materi dalam Musyarah Perencanaan Pembangunan kecamatan dan kabupaten/kota. Adapun alur penyusunan RKP dapat dilihat dalam bagan dibawah ini:

\section{Bagan 1.}

Alur Penyusunan RKP Desa Berdasarkan Permendagri No. 114/2014

Tentang Pedoman Pembangunan Desa.

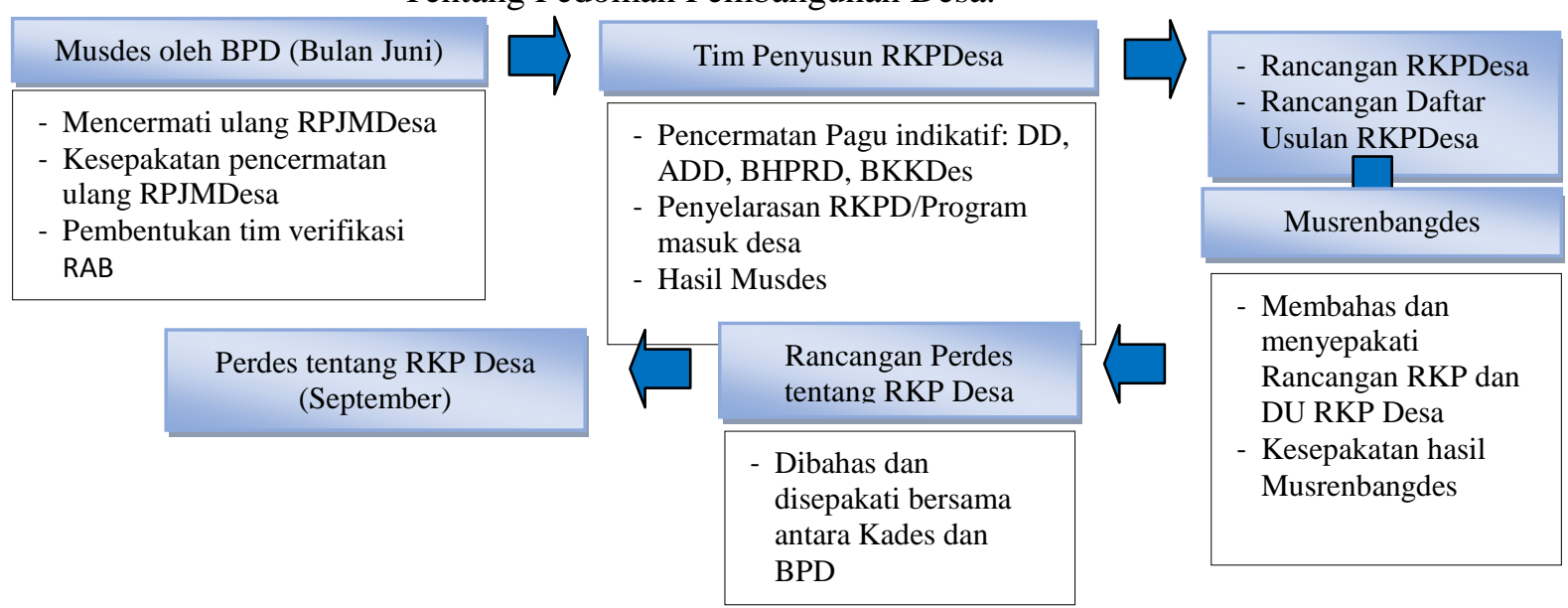

Sumber: Analisis peneliti, 2021.

Alur penyusunan RKP Desa ini mulai berlaku sejak Peraturan Menteri Dalam Negeri ini ditetapkan, yakni tanggal 31 Desember 2014. Akan tetapi, peraturan ini memberikan kelonggaran bagi desa yang sudah memiliki RKP Desa untuk tetap melaksanakan RKP Desa tersebut sampai dengan berakhir masa berlakunya. Penelitian yang dilakukan oleh SMERU research institute terkait dengan proses perencanaan dan penganggaran di desa yang dilakukan di 3 provinsi, 5 kabupaten, dan 10 desa ( 2 desa per kabupaten) menunjukkan bahwa adanya kegiatan-kegiatan yang tidak terlaksana secara optimal karena perencanaan yang kurang baik dan perencanaan yang ada masih bersifat sporadis dan miskin ide (Bachtiar, 2018). Pada tanggal 22 Oktober 2019 diundangkanlah Peraturan Menteri Desa, Pembangunan Daerah Tertinggal dan transmigrasi No. 17 Tahun 2019 Tentang Pedoman Umum Pembangunan dan Pemberdayaan masyarakat desa. Regulasi yang dikeluarkan oleh Kementrian Desa ini juga mengatur tentang Penyusunan RKP Desa yang terdapat dalam pasal 24 hingga pasal 45. Dengan demikian ada 2 regulasi yang mengatur tentang teknis penyusunan RKP Desa karena Permendesa ini tidak membatalkan Permendagri No. 114/2014 yang juga mengatur tentang teknis penyusunan RKP Desa.

Tahapan penyusunan RKP Desa yang diatur melalui Permendesa ini dimulai dari musyawarah perencanaan pembangunan tahunan yang dilaksanakan paling lambat bulan Juni tahun berjalan. Setelah musdes, dibentuklah tim penyusun RKP Desa yang berjumlah paling sedikit 7 orang dengan memperhatikan keterwakilan perempuan. Tim ini terdiri dari kepala desa sebagai pembina, ketua tim yang dipilih berdasarkan musyawarah mufakat dengan mempertimbangkan kemampuan dan keahlian, sekretaris tim yang ditunjuk oleh ketua tim, dan anggota yang berasal dari perangkat desa, kader pemberdayaan masyarakat desa serta unsur masyarakat desa lainnya (pasal 27 ayat 2). Tim RKP Desa mulai bekerja setelah ditetapkan dengan surat Keputusan Kepala Desa. Tim ini memiliki tugas melakukan a) percermatan 
perkiraan pendapatan desa; b) pencermatan ulang dokumen RPJM Desa; c) penyusunan rancangan RKP Desa; d) penyusunan rancangan daftar usulan RKP Desa; dan e) penyusunan desain dan RAB kegiatan. Tim menyerahkan rancangan RKP dan DU RKP Desa jika telah selesai yang dilengkapi dengan berita acara.

Setelah tim RKP Desa menyelesaikan pekerjaannya, kepala desa kemudian melakukan musrenbang desa untuk membahas dan menyepakati rancangan RKP Desa. Pembahasan dan penyepakatan rancangan RKP Desa terkait dengan pembidangan program dan kegiatan beserta sumber pendanaannya dan prioritas program dan/atau kegiatan. Hasil kesepakatan musrenbang desa ini kemudian dituangkan dalam berita acara dan disampaikan oleh kepala desa kepada BPD. Tahapan selanjutnya adalah musyawarah desa untuk melakukan pembahasan dan penetapan RKP Desa yang dilakukan oleh BPD. Agenda dari musyawarah ini adalah pelaporan hasil rancangan RKP Desa dan pembahasan dan penetapan RKP Desa kemudian dituangkan dalam matrik rencana program dan kegiatan tahunan. Untuk lebih jelasnya dapat dilihat pada bagan 2.

\section{Bagan 2.}

Alur Penyusunan RKP Desa Berdasarkan Permendesa No. 17/2019

Tentang Pedoman Umum Pembangunan dan Pemberdayaan Masyarakat Desa.

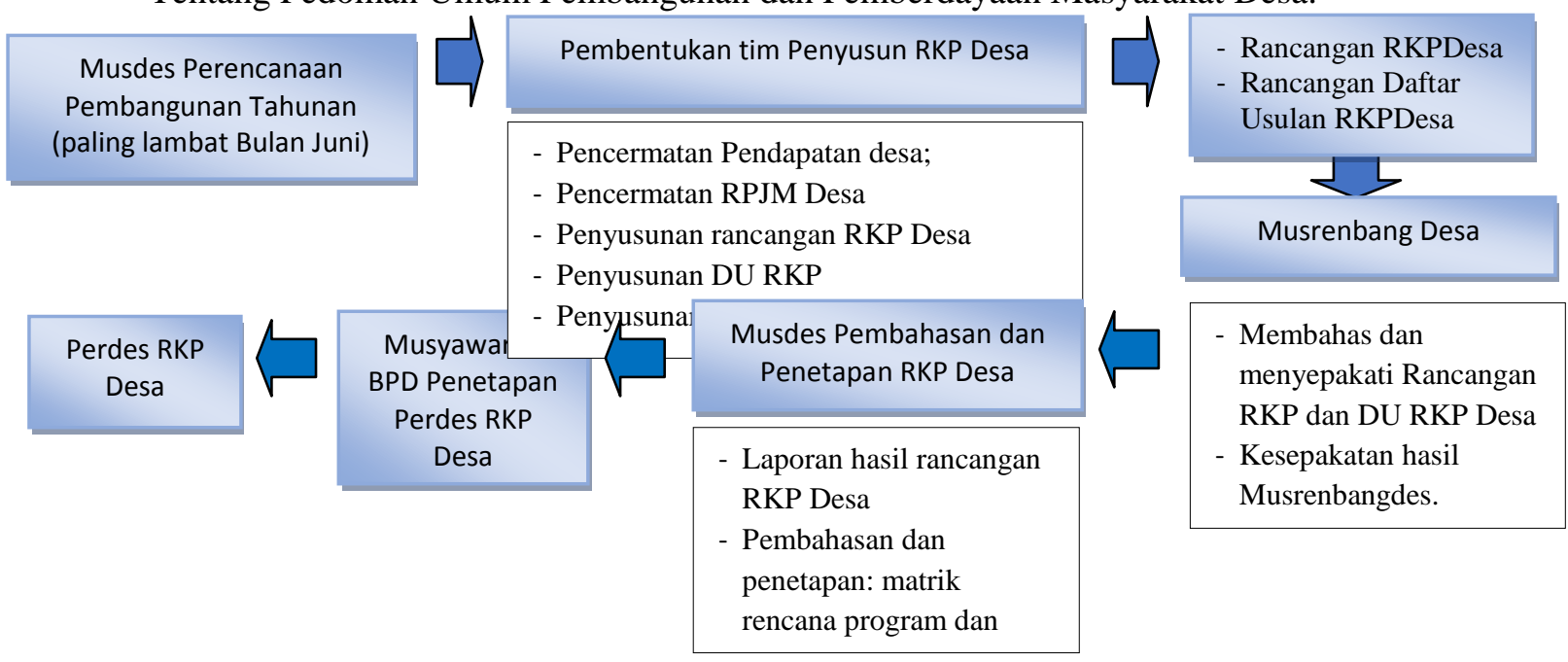

Sumber: Analisis Peneliti, 2021.

Jika dilihat dari kedua regulasi diatas, terdapat perbedaan pengaturan terkait dengan teknis penyusunan RKP Desa. Perbedaan tersebut dapat dilihat pada tabel 1.

Tabel 1. Perbedaan Teknis Penyusunan RKP Desa berdasarkan Permendagri No. 114 tahun

2014 tentang Pedoman Pembangunan Desa dan Permendesa No. 17 tahun 2019 tentang

Pedoman Umum Pembangunan dan Pemberdayaan Masyarakat Desa.

\begin{tabular}{|c|c|c|}
\hline & $\begin{array}{c}\text { Permendagri No. 114/2014 } \\
\text { tentang Pedoman } \\
\text { Pembangunan Desa }\end{array}$ & $\begin{array}{l}\text { Permendesa No. 17/2019 tentang } \\
\text { Pedoman Umum Pembangunan dan } \\
\text { Pemberdayaan Masyarakat Desa }\end{array}$ \\
\hline $\begin{array}{l}\text { Waktu } \\
\text { Penyusunan } \\
\text { RKP Desa }\end{array}$ & $\begin{array}{l}\text { - Disusun pada bulan Juli } \\
\text { tahun berjalan (pasal 29) }\end{array}$ & $\begin{array}{l}\text { - Disusun paling lambat Bulan Juni } \\
\text { tahun berjalan (pasal } 26 \text { ayat (2) }\end{array}$ \\
\hline $\begin{array}{l}\text { Tim Penyusun } \\
\text { RKP Desa }\end{array}$ & $\begin{array}{l}\text { Tim RKP terdiri dari: } \\
\text { 1. Kepala Desa sebagai } \\
\text { Pembina; } \\
\text { 2. Sekretaris desa selaku } \\
\text { ketua; } \\
\text { 3. Ketua LPM sebagai } \\
\text { sekretaris; }\end{array}$ & $\begin{array}{l}\text { - Tim RKP terdiri dari: } \\
\text { 1. Kepala desa sebagai Pembina; } \\
\text { 2. Ketua yang dipilih secara } \\
\text { musyawarah dan mufakat dengan } \\
\text { mempertimbangkan keahlian dan } \\
\text { kemampuan; } \\
\text { 3. Sekretaris yang ditunjuk oleh }\end{array}$ \\
\hline 386 & nelitian dan Pe & $\begin{array}{l}\text { E-ISSN: } 2657-0300 \\
\text { P-ISSN: } 2657-0319\end{array}$ \\
\hline
\end{tabular}




\begin{tabular}{|c|c|c|}
\hline & $\begin{array}{l}\text { 4. Anggota; perangkat desa, } \\
\text { LPM, KPMD, dan unsur } \\
\text { masyarakat (pasal } 33 \\
\text { ayat 2) }\end{array}$ & $\begin{array}{l}\text { ketua tim; } \\
\text { 4. Anggota: perangkat desa, KPMD, } \\
\text { dan unsur masyarakat lainnya } \\
\text { (pasal } 27 \text { ayat 2) }\end{array}$ \\
\hline $\begin{array}{l}\text { Jumlah Tim } \\
\text { Penyusun } \\
\text { RKP Desa }\end{array}$ & $\begin{array}{l}\text { - Paling sedikit } 7 \text { orang } \\
\text { dan paling banyak } 11 \\
\text { orang (pasal } 33 \text { ayat } 3 \text { ) }\end{array}$ & $\begin{array}{l}\text { - Paling sedikit berjumlah } 7 \text { orang } \\
\text { dengan mempertimbangkan kesetaraan } \\
\text { dan keadilan gender (pasal } 27 \text { ayat } 4 \text { ) }\end{array}$ \\
\hline $\begin{array}{l}\text { Tugas Tim } \\
\text { RKP Desa }\end{array}$ & $\begin{array}{l}\text { Tugas tim RKP Desa: } \\
\text { a.Pencermatan pagu } \\
\text { indikatif dan } \\
\text { penyelarasan program } \\
\text { yang masuk ke desa; } \\
\text { b.Pencermatan ulang } \\
\text { dokumen RPJM Desa; } \\
\text { c.Penyusunan rancangan } \\
\text { RKP Desa; } \\
\text { d.Penyusunan rancangan } \\
\text { DU RKP Desa (pasal 34) }\end{array}$ & $\begin{array}{l}\text { Tugas tim RKP Desa: } \\
\text { a. Pencermatan perkiraan pendapatan } \\
\text { desa; } \\
\text { b. Pencermatan ulang dokumen } \\
\text { RPJM Desa; } \\
\text { c. Penyusunan rancangan RKP Desa; } \\
\text { d. Penyusunan rancangan DU RKP } \\
\text { Desa; } \\
\text { e. penyusunan desain dan RAB } \\
\text { kegiatan (pasal 28) }\end{array}$ \\
\hline $\begin{array}{l}\text { Penetapan } \\
\text { RKP Desa }\end{array}$ & $\begin{array}{l}\text { Rancangan Peraturan } \\
\text { desa tentang RKP Desa } \\
\text { dibahas dan disepakati } \\
\text { bersama antara kepala } \\
\text { desa dan BPD (pasal } 48 \\
\text { ayat 5) }\end{array}$ & 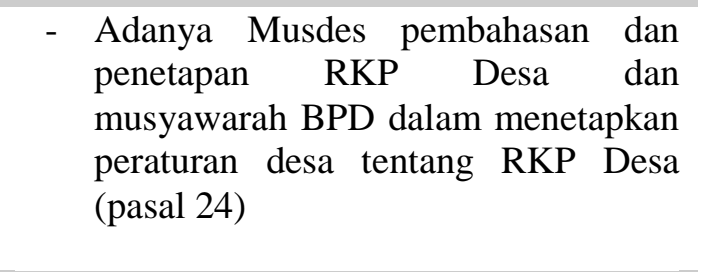 \\
\hline $\begin{array}{l}\text { Penyusunan } \\
\text { RKP Desa oleh } \\
\text { Pejabat } \\
\text { Kepala Desa }\end{array}$ & Tidak Mengatur & $\begin{array}{l}\text { - Pejabat kepala desa dapat Menyusun } \\
\text { RKP Desa untuk tahun berikutnya } \\
\text { melalui Musrenbang desa dengan } \\
\text { berpedoman kepada hasil evaluasi } \\
\text { RPJM tahun sebelumnya, arah } \\
\text { kebijakan pembangunan } \\
\text { kabupaten/kota dan percermatan } \\
\text { terhadap perkembangan desa (pasal } \\
\text { 45) }\end{array}$ \\
\hline
\end{tabular}

Sumber: Analisis peneliti, 2021.

Peraturan Menteri Desa PDTT No. 17/2019 tentang Pedoman Umum Pembangunan dan Pemberdayaan Masyarakat Desa ini kemudian dicabut dan digantikan dengan Peraturan Menteri Desa PDTT No. 21/2020 Tentang Pedoman Umum Pembangunan dan pemberdayaan Masyarakat Desa yang diundangkan pada tanggal 28 Desember 2020. Peraturan ini direvisi karena adanya perubahan tujuan pembangunan dan pemberdayaan masyarakat yang memfokuskan arah kebijakan perencanaan pembangunan desa pada pencapaian SDGs Desa. SDGs Desa adalah upaya terpadu Pembangunan Desa untuk percepatan pencapaian tujuan pembangunan berkelanjutan. Permendesa No. 21/2020 ini memiliki pengaturan yang berbeda dalam tahapan penyusunan RKP Desa. Adapun tahapan penyusunan RKP Desa dimulai dari Pembentukan tim penyusun RKP Desa. Dari penjelasan pasal sebelumnya, disebutkan bahwa penyusunan RKP Desa harus memperhatikan usulan masyarakat dea tentang program dan/atau kegiatan pembangunan desa untuk pencapaian SDGs Desa. Tim ini berjumlah minimal 7 orang dan maksimalnya tidak ditentukan. Tugas dari tim ini adalah Menyusun RKP dan DU RKP Desa.

Setelah tim terbentuk yang dibuktikan dengan terbitnya SK kepala desa maka tahapan selanjutnya adalah tim bekerja untuk melakukan penyelarasan rencana kegiatan dan pembiayaan pembangunan desa, pencermatan ulang RPJM Desa, serta penyusunan RKP dan DU RKP Desa. Jika rancangan RKP Dan DU RKP Desa selesai, kepala desa kemudian melakukan Musrenbang desa untuk membahas RKP dan DU RKP Desa. Tahapan terakhir 
adalah dilakukannya muyawarah desa untuk melakukan pembahasan dan pengesahan RKP Desa dan DU RKP Desa. Adapun alur dari tahapan penyusunan RKP Desa menurut regulasi ini dapat dilihat pada bagan 3 .

\section{Bagan 3.}

Alur Penyusunan RKP Desa Berdasarkan Permendesa No. 21/2020

Tentang Pedoman Umum Pembangunan dan Pemberdayaan Masyarakat Desa.

Pembentukan tim Penyusun RKP Desa
- Pencermatan dan penyelarasan
rencana kegiatan dan pembiayaan
pembangunan desa;
- Pencermatan ulang RPJM Desa;
- Penyusunan rancangan RKP Desa
- Penyusunan DU RKP Desa
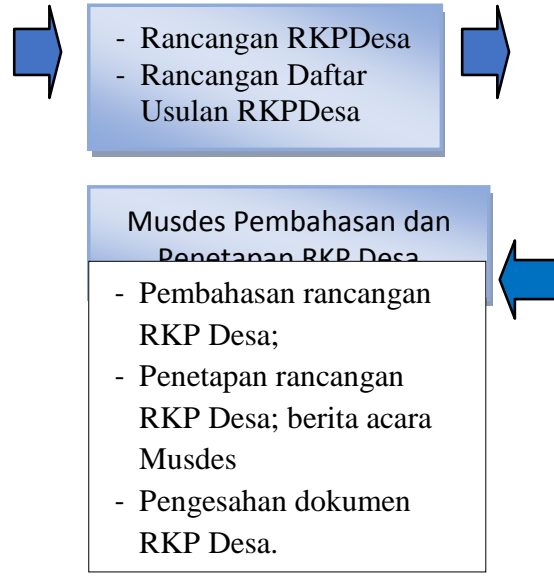

Sumber: Analisis Peneliti, 2021.

Peraturan Menteri Desa PDTT No. 21/2020 ini, memiliki persamaan dan perbedaan teknis dalam penyusunan RKP Desa dengan Permendagri No. 114/2014. Perbedaan tersebut dapat dilihat pada tabel 2.

Tabel 2. Persamaan dan Perbedaan Teknis Penyusunan RKP Desa berdasarkan Permendagri No. 114 tahun 2014 tentang Pedoman Pembangunan Desa dan Permendesa No. 21 tahun 2020 tentang Pedoman Umum Pembangunan dan Pemberdayaan Masyarakat Desa.

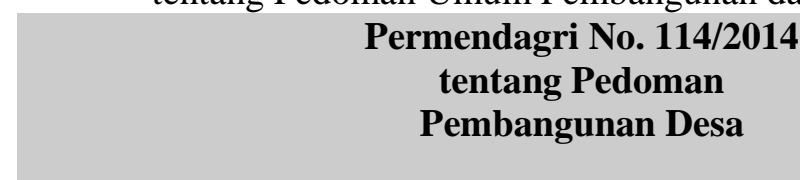

Waktu

Penyusunan

RKP Desa
- Disusun pada bulan Juli tahun berjalan dan ditetapkan paling lambat pada akhir bulan September tahun berjalan (pasal 29 ayat 3 dan 4)
Permendesa No. 21/2020 tentang Pedoman Umum Pembangunan dan Pemberdayaan Masyarakat Desa

- Disusun pada Bulan Juli tahun berjalan dan ditetapkan paling lambat pada akhir bulan September tahun berjalan (pasal 22 ayat (4)

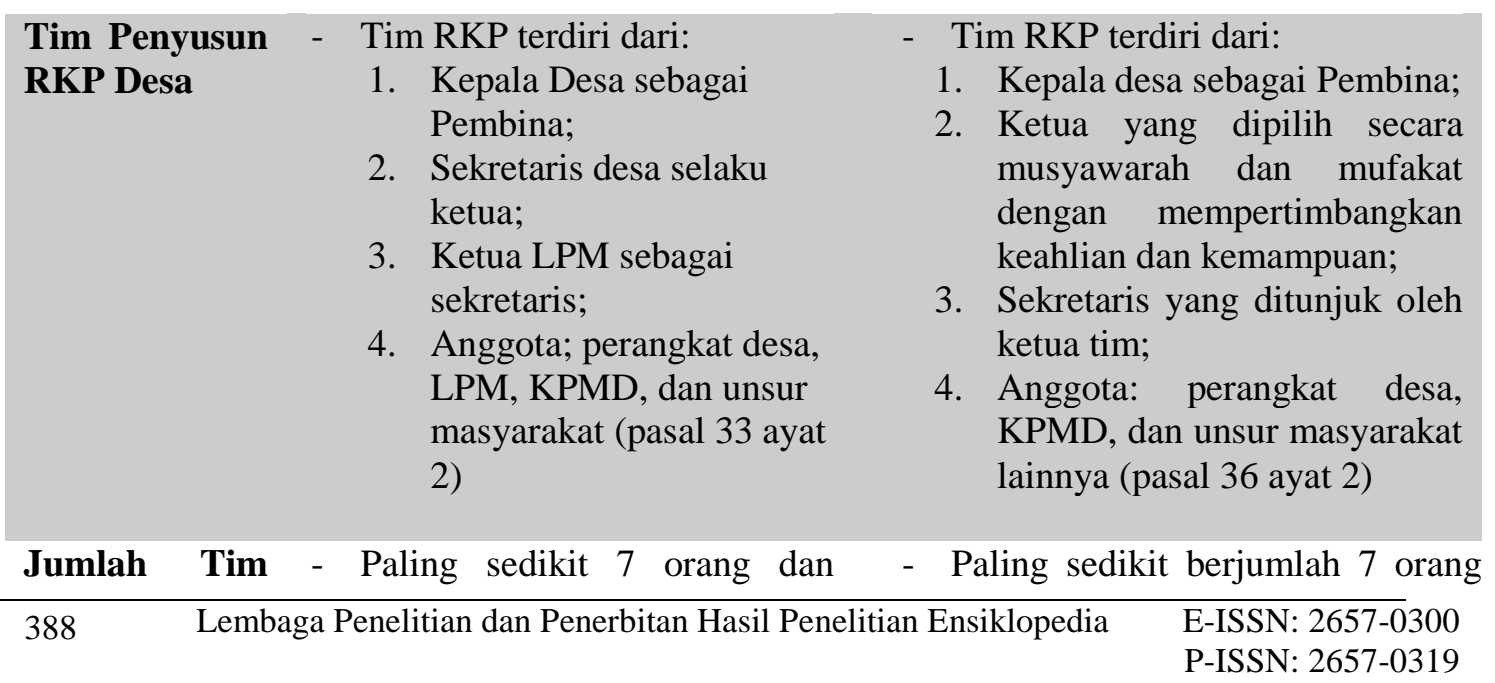




\begin{tabular}{|c|c|c|}
\hline $\begin{array}{l}\text { Penyusun } \\
\text { RKP Desa }\end{array}$ & $\begin{array}{l}\text { paling banyak } 11 \text { orang (pasal } \\
33 \text { ayat } 3 \text { ) }\end{array}$ & $\begin{array}{l}\text { dengan mempertimbangkan } \\
\text { kesetaraan dan keadilan gender } \\
\text { (pasal } 27 \text { ayat } 4 \text { ) }\end{array}$ \\
\hline $\begin{array}{l}\text { Tugas Tim } \\
\text { RKP Desa }\end{array}$ & $\begin{array}{l}\text { Tugas tim RKP Desa: } \\
\text { 1. Pencermatan pagu } \\
\text { indikatif dan penyelarasan } \\
\text { program yang masuk ke } \\
\text { desa; } \\
\text { 2. Pencermatan ulang } \\
\text { dokumen RPJM Desa; } \\
\text { 3. Penyusunan rancangan } \\
\text { RKP Desa; } \\
\text { 4. Penyusunan rancangan } \\
\text { DU RKP Desa (pasal 34) }\end{array}$ & $\begin{array}{l}\text { Tugas tim RKP Desa: } \\
\text { 1. Penyusunan rancangan RKP } \\
\text { Desa dan Penyusunan } \\
\text { rancangan DU RKP Desa. } \\
\text { Dengan tahapan: } \\
\text { - Pencermatan dan } \\
\text { penyelarasan rencana } \\
\text { kegiatan dan pembiayaan } \\
\text { pembangunan desa; } \\
\text { - Pencermatan ulang RPJM } \\
\text { Desa; rangan rancangan RKP } \\
\text { - Penyusunan ran } \\
\text { Desa dan DU RKP Desa; } \\
\text { - Penyusunan rencana } \\
\text { kegiatan, serta desain teknis } \\
\text { dan RAB kegiatan (pasal } \\
\text { 37) }\end{array}$ \\
\hline
\end{tabular}

$\begin{array}{ll}\begin{array}{l}\text { Tahapan } \\ \text { Penyusunan } \\ \text { RKP Desa }\end{array} & -\begin{array}{l}\text { Tahapan penyusunan meliputi: } \\ \text { a. Musdes perencanaan } \\ \text { pembangunan; }\end{array} \\ & \text { b. Pembentukan tim penyusun } \\ & \text { RKP Desa; } \\ \text { c. Pencermatan pagu indikatif } \\ \text { desa dan program } \\ \text { pembangunan yang masuk } \\ \text { ke desa; } \\ \text { d. Percermatan ulang RPJM } \\ \\ \text { e. Desa; } \\ \text { f. Pusrenbang Desa; } \\ \text { g. Pengajuan RKP; RKP Desa } \\ \text { (Pasal 30) }\end{array}$

\begin{tabular}{|c|c|}
\hline $\begin{array}{l}\text { Penetapan } \\
\text { RKP Desa }\end{array}$ & $\begin{array}{l}\text { Rancangan Peraturan desa } \\
\text { tentang RKP Desa dibahas dan } \\
\text { disepakati bersama antara } \\
\text { kepala desa dan BPD (pasal } \\
48 \text { ayat 5) }\end{array}$ \\
\hline
\end{tabular}

\section{Penyusunan}

Tidak Mengatur

T. Pembentukan tim penyusun

$$
\text { RKP Desa; }
$$

b. Pencermatan dan penyelarasan rencana kegiatan dan pembiayaan pembangunan desa;

c. Percermatan ulang RPJM Desa;

d. Penyusunan rancangan RKP Desa dan DU RKP Desa;

e. Musrenbang Desa;

f. Musyawarah desa pembahasan dan pengesahan RKP Desa dan DU RKP Desa

(Pasal 34)

\section{RKP Desa \\ oleh Pejabat \\ Kepala Desa}

Sumber: Analisis peneliti, 2021

Dari tabel diatas terlihat bahwasannya untuk waktu penyusunan RKP Desa sama-sama diatur pelaksanaannya dimulai pada Bulan Juli dan ditetapkan paling lambat Bulan September tahun berjalan. Begitu pula dengan tugas tim RKP Desa, dari kedua regulasi tersebut tidak ada 
perbedaan dalam hal pengaturan tugas tim serta kedua regulasi ini sama-sama tidak mengatur bagaimana penyusunan RKP Desa oleh pejabat kepala desa. Akan tetapi, ada beberapa peerbedaan pengaturan terkait dengan penyusunan RKP Desa dari kedua regulasi ini, yakni komposisi tim penyusun RKP Desa, jumlah tim penyusun RKP Desa, dan penetapan RKP Desa serta tahapan dalam penyusunan RKP Desa.

\section{Dampak Tumpang Tindih Regulasi Dalam Penyusunan RKP Desa Tahun 2022.}

Ada 2 (dua) dampak yang ditimbulkan dari tumpang tindih regulasi dalam penyusunan RKP Desa ini: a) Regulasi yang terus berubah terkait pengaturan tentang desa ini membuat pemerintah Kabupaten lambat merevisi regulasi di daerah. Dalam Permendagri No. 114/2014 di bab penutup pasal 89 dijelaskan bahwa petunjuk teknis penyusunan RPJM Desa dan RKP Desa serta petunjuk teknis pelaksanaan kegiatan pembangunan desa lebih lanjut diatur dengan peraturan bupati/walikota. Berdasarkan pasal tersebut, Kabupaten 50 Kota Provinsi Sumatera Barat menerbitkan Peraturan Bupati No. 28 Tahun 2019 tentang Petunjuk Teknis Penyusunan RPJM Nagari, RKP Nagari dan Pelaksanaan Kegiatan Pembangunan Nagari. Peraturan bupati ini baru ditetapkan dan diundangkan pada tanggal 24 Juni 2019. Terlihat bahwa Pemerintah Kabupaten 50 Kota baru merespon pasal tersebut 5 tahun sejak ditetapkan dan diundangkannya Permendagri No. 114/2014.

Setelah 4 bulan peraturan bupati ini diundangkan, maka lahirlah Permendesa PDTT No. 17/2019 yang juga mengatur tentang pedoman umum pembangunan dan pemberdayaan masyarakat desa. Seperti yang telah dijelaskan diatas bahwasannya ada beberapa pengaturan yang berbeda dari regulasi ini. Seharusnya pemerintah Kabupaten 50 Kota cepat tanggap terkait dengan hal ini yakni dengan segera melakukan revisi terhadap Peraturan Bupati No. 28/2019. Peraturan bupati seharusnya mengakomodir tumpang tindih regulasi dalam penyusunan RKP Desa ini sehingga tidak menimbulkan kebingungan pemerintahan nagari dalam penyusunan RKP Nagari tahun 2021 karena perencanaan pembangunan dan pemberdayaan masyarakat desa harus menyesuaikan dengan ketentuan peraturan menteri ini paling lama 1 (satu) tahun sejak peraturan Menteri ini diundangkan. Pada tahun berikutnya, yakni tanggal 21 Desember 2020 Kementrian Desa PDTT mencabut Permendesa No. 17/2019 dan menggantinya dengan Permendesa PDTT No. 21/2020 masih mengatur hal yang sama. Peraturan menteri desa No. 21/2020 ini lebih memfokuskan pembangunan desa kepada pencapaian SDGs Desa. Dengan keluarnya regulasi ini, pendataan desa dan perencanaan pembangunan desa harus menyesuaikan dengan ketentuan peraturan Menteri ini paling lama 1 tahun sejak peraturan Menteri ini diundangkan. Peraturan Bupati 50 Kota No. 28/2019 hingga saat penelitian ini dilakukan belum menyesuaikan dengan regulasi tersebut.

Dengan belum adanya revisi dari Peraturan Bupati tersebut menimbulkan kebingungan pada pemerintahan nagari yang akan menyusun RKP Nagari tahun 2022 karena ada perbedaan teknis dalam tahapan penyusunan RKP Desa dan juga matrik RKP Desa. Untuk penyusunan RKP Nagari tahun 2022 pemerintah Kabupaten 50 Kota mengeluarkan surat edaran No. 414.2/299/DPMDN/2021 pada tanggal 11 Juni 2021. Dalam surat tersebut tahapan penyusunan dan matrik RKP Nagari masih berdasarkan Permendagri No. 114/2014. Hal ini tentu saja membuat bingung pemerintahan nagari karena nagari telah melaksanakan pendataan SDGs dengan menggunakan dana desa tahun 2021. Amanah dari Permendesa No. 21/2020 adalah perencanaan desa berbasiskan pada data SDGs, sedangkan tahapan penyusunan dan matrik RKP Nagari masih berdasarkan Permendagri No. 114/2014. Dari hasil penelitian yang dilakukan peneliti adanya tumpang tindih regulasi ini membuat bingung pemerintahan nagari dan akhirnya pemerintahan nagari mengkolaborasi sendiri teknis penyusunan RKP Nagari berdasarkan Permendagri No. 114/2014 dan Permendesa No. 21/2020. Untuk matrik RKP Nagari, 79 nagari yang ada di Kabupaten 50 Kota mengikuti matrik yang ada di dalam Permendesa PDTT No. 21/2020 bukan yang ada dalam surat edaran bupati. Hal ini terjadi karena adanya pendamping desa yang mengarahkan nagari untuk menggunakan tahapan penyusunan dan matrik RKP berdasarkan Permendesa PDTT No. 21/2020.

390 Lembaga Penelitian dan Penerbitan Hasil Penelitian Ensiklopedia $\quad$ E-ISSN: 2657-0300

P-ISSN: 2657-0319 
b) Munculnya Perselisihan di Internal Pemerintahan Nagari. Tumpang tindih regulasi dalam penyusunan RKP Desa yang kemudian tidak disikapi dengan adanya kolaborasi regulasi di tingkat daerah dapat menimbulkan konflik di pemerintahan nagari. Hal ini terjadi di salah satu nagari yang ada di Kabupaten 50 Kota. Di internal pemerintahan nagari terpecah terkait dengan teknis tahapan penyusunan RKP Nagari ini, ada perangkat nagari yang pro untuk mengikuti seluruh tahapan berdasarkan Permendesa No. 21/2020 dan ada perangkat nagari yang setuju untuk mengkolaborasi kedua regulasi tersebut dalam penyusunan RKP Nagari tahun 2022. Masalah yang diperdebatkan hingga belum selesainya RKP Nagari tahun 2022 hingga penelitian ini selesai dilakukan adalah terkait dengan adanya tim verifikasi proposal usulan kegiatan. Jika merujuk pada Permendagri No. 114/2014, tim verifikasi ini dibentuk pada saat musyawarah desa (pasal 32). Dalam Permendesa PDTT No. 21/2020 tidak ada mengatur terkait dengan tim verifikasi ini karena desain dan RAB kegiatan dibuat oleh tim RKP Desa.

\section{Penutup}

Kesimpulan yang dapat dikemukakan adalah sebagai berikut; pertama, perencanaan pembangunan desa merupakan hal yang sangat penting karena dokumen ini merupakan pedoman dalam pelaksanaan pembangunan di desa. Perencanaan pembangunan desa terdiri dari 2 (dua) bentuk yakni, RPJM Desa dan RKP Desa. Tanpa ada dokumen perencanaan pembangunan desa ini, maka desa/nagari tidak dapat menyusun Anggaran Pendapatan dan Belanja desa/nagari. Undang-undang Desa No. 6/2014 membutuhkan banyak regulasi turunan agar teknis di lapangan mudah dilaksanakan. Kementrian yang kemudian membidangi ini adalah kementrian Dalam Negeri dan kementrian Desa, Pembangunan Daerah Tertinggal dan Transmigrasi. Namun, kedua kementrian ini acap kali tumpang tindih dalam pengaturan teknis, seperti tentang pedoman umum pembangunan dan pemberdayaan masyarakat desa. Kedua, tumpang tindih regulasi terkait dengan penyusunan RKP Desa ini menimbulkan dampak, yakni regulasi yang sering berubah terkait dengan pengaturan desa ini membuat pemerintah kabupaten menjadi lambat dalam merevisi peraturan yang ada di daerah dan munculnya perselisihan di internal pemerintahan nagari dalam penyusunan RKP Nagari tahun 2022.

\section{Daftar Pustaka}

Abikusna, R. A. (2020). Kewenangan Desa Dalam Penanggulangan Covid-19. Sosfilkom, 14 (2), 25-38. https://ojs3.umc.ac.id/index.php/SFK/article/view/1525

Bachrein, S. (2010). Pendekatan Desa Membangun di Jawa Barat: Strategi dan Kebijakan Pembangunan Perdesaan. Analisis Kebijakan Pertanian, 8 (2). http://ejurnal.litbang.pertanian.go.id/index.php/akp/article/view/4227

Bachtiar, P. (2018). Pemantauan Implementasi UU Desa "Proses Perencanaan dan Penganggaran di Desa."

Buku Bantu Pengelolaan Pembangunan Desa. (2016). Deputi Koordinasi Pemberdayaan Masyarakat, Desa, dan Kawasan Kementrian Koordinator Bidang Pembangunan Manusia dan Kebudayaan Republik Indonesia.

Chandra, H. S. (2019). Penataan Peraturan Menteri Sebagai Upaya Reformasi Regulasi Di Indonesia. In Menggagas Arah Kebijakan Reformasi Regulasi di Indonesia: Prosiding Forum Akademik Kebijakan Reformasi Regulasi 2019 (Cetakan Pe, pp. 2-19). Yayasan Studi Hukum dan Kebijakan Indonesia (YSHK).

Mali, Y. A., Uskono, N., \& Taus, W. (2019). Koordinasi Pemerintah Desa Dalam Penyusunan Rencana Kerja Pemerintah Desa (RKP Desa). JIANE (Jurnal Ilmu Administrasi Negara), 1(1), 56-72. https://jurnal.unimor.ac.id/JIANE/article/view/364

Rudiadi, Ilosa, A., \& Al Sukri, S. (2021). Optimalisasi Kinerja Pemerintahan Desa Dalam Penyusunan. El -Riyasah, 12(1), 44-58. http://ejournal.uinsuska.ac.id/index.php/elriyasah/article/view/13201/6617

Silalahi, U. (2010). Metode Penelitian Sosial (A. Gunarsa (Ed.); Kedua). PT. Refika Aditama. Suprastiyo, A., \& Musta'ana, M. (2019). IMPLEMENTASI PENYUSUNAN RENCANA 
KERJA (RKP) DESA (Studi Di Desa Trucuk Kecamatan Trucuk Kabupaten Bojonegoro). Jurnal Ilmiah Manajemen Publik Dan Kebijakan Sosial, 2(2), 255-263. http://61.8.70.50/index.php/negara/article/view/1359

Undang-undang No. 6 Tahun 2014 Tentang Desa

Peraturan Menteri Dalam Negeri No. 114 Tahun 2014 tentang Pedoman Umum Pembangunan Desa

Peraturan Menteri Desa, Pembangunan Daerah Tertinggal dan Transmigrasi No. 17 tahun 2019 tentang Pedoman Umum Pembangunan dan pemberdayaan Masyarakat Desa.

Peraturan Menteri Desa, Pembangunan Daerah Tertinggal dan Transmigrasi No. 20 tahun 2021 tentang Pedoman Umum Pembangunan dan pemberdayaan Masyarakat Desa. 